\title{
INCREASING THE USE AND DEMAND FOR LOW-CARBON WIRES PRODUCED IN SECONDARY METALLURGICAL PRODUCTION IN THE CZECH REPUBLIC
}

\author{
Iveta KUCHTÍČKOVÁ, Václav NÉTEK, Nikola NĚMCOVÁ \\ ${ }^{1}$ VSB - Technical University of Ostrava, Faculty of Materials Science and Technology, Ostrava, \\ Czech Republic, EU, Kuchtickoval@seznam.cz
}

https://doi.org/10.37904/metal.2021.4283

\begin{abstract}
The paper examines the issue of increasing the use and demand for low-carbon wire produced in secondary metallurgical production in the Czech Republic, which is important in fields which support development in industries such as transport, electricity production, medicine, food, aerospace, armaments and education. Research through surveys, determination of the links in this area, and establishment of the hypotheses and evidence for the need to address this current topic has provided knowledge which can potentially increase the added value of low-carbon wire.
\end{abstract}

Keywords: Low carbon wire, metallurgy, higher degree of appreciation, secondary metallurgical production

\section{INTRODUCTION}

The issue of increasing the use and demand for low-carbon wire produced in certain branches of secondary metallurgical production in the Czech Republic carries its own pitfalls but is nonetheless an important link to branches of primary metallurgy which support the development of production under certain technological chains. The research on this current issue gathers knowledge to create value in the low added value status of low-carbon wire.

The aim is to highlight some of the problems which exist in the technological chain of low-carbon wire production in certain areas of secondary metallurgical production in the Czech Republic and to acquire research knowledge for potential solutions.

\section{INTRODUCTION TO THE ISSUE OF INCREASING THE USE AND DEMAND FOR LOW-CARBON WIRE PRODUCED IN THE CZECH REPUBLIC}

The issue of a higher degree of added value in low-carbon wire produced in the Czech Republic is compromised by disconnection with the technological chains of secondary metallurgical production and engineering from the perspective of capital structure.

Research conducted at finishing companies in the Czech Republic has shown that recent or already defunct companies have not been able to compete with their counterparts. From a dozen or so screw mill operations in the Czech Republic, only two still exist. With respect to the available range of products, the research points to, for example, phosphated wire and copper-plated wire, which are currently not part of the technological chain of domestic Czech manufacturers. The technologies capable of finishing production are not resilient towards the high pressure of competition generated by other technologies.

\subsection{Low-carbon wire production in the Czech Republic}

Low-carbon wire is produced at the companies ŽDB DRÁTOVNA a.s. in Bohumín and HŽP a.s. in Prostějov. Supply requirements are currently fragmented into a small number of deliveries, creating the space for 
competing subcontractors and suppliers on the Czech Republic's domestic market. The environment is represented by the diagram in Figure 1.

Production at ŽDB DRÁTOVNA a.s. is focused on the processing of rolled wire. An integral part of the wire shop is a drawing plant for the production of non-patented wire (low carbon) and light annealed and semi-hard wire with material quality in accordance with the standard EN 16120-2. Since 2012, ŽDB DRÁTOVNA a.s. has been a subsidiary of TŘINECKÉ ŽELEZÁRNY a.s. (Trinec Iron Works, Inc.). This company has a number of operations, including a patented wire drawing plant, low-carbon wire production, a rope making plant, steel cord production, spring production and other wire production. The company's proportion of exported products (certificate in accordance with EN ISO 9001: 2008, ISO / TS 16949: 2009) is more than $80 \%$ [1,2].

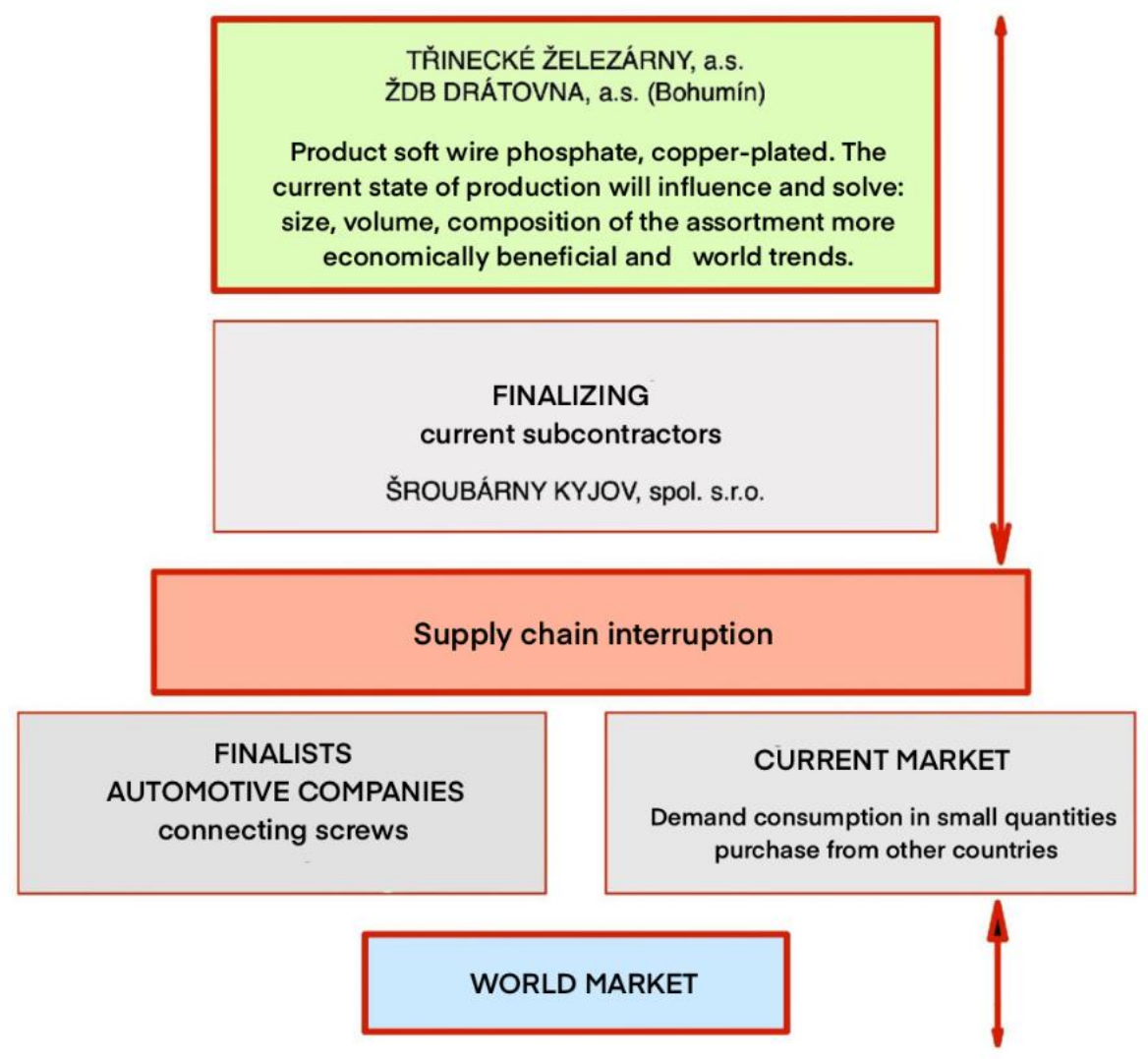

Figure 1 Environment of low-carbon wire supplier and consumer (screw shops, spring plants) in the Czech Republic

\subsection{Research findings}

The outcomes of developments in low-carbon wire production in relation to distribution are as follows:

- Disconnection of the production and supply chain of low-carbon wire due to the number of deliveries and amount of production required in the Czech Republic.

- Economic motivation for the demand and production of low-carbon wire manufactured in the Czech Republic.

- Coverage and interconnection of domestic demand and production in terms of capital structure (i.e., in the Czech Republic). 


\section{ANALYSIS OF THE DEVELOPMENT OF NEW OPPORTUNITIES}

Analysis of the research was performed by mapping the market, conducting a literature review, and conducting questionnaire surveys in cooperation with RMTVC (Regional Materials Science and Technology Centre).

A large proportion of low-carbon wire production (92\%) is destined for import by car manufacturers. However, car manufacturers do not use the production of Czech finishing companies and thus do not create added value for low-carbon wire in the country. Despite this, Czech manufacturers possess the technology to produce these products. Manufacturers who use these products could source production in the country but instead purchase from other suppliers. The proportion of use by the automotive industry is shown in Figure 2.
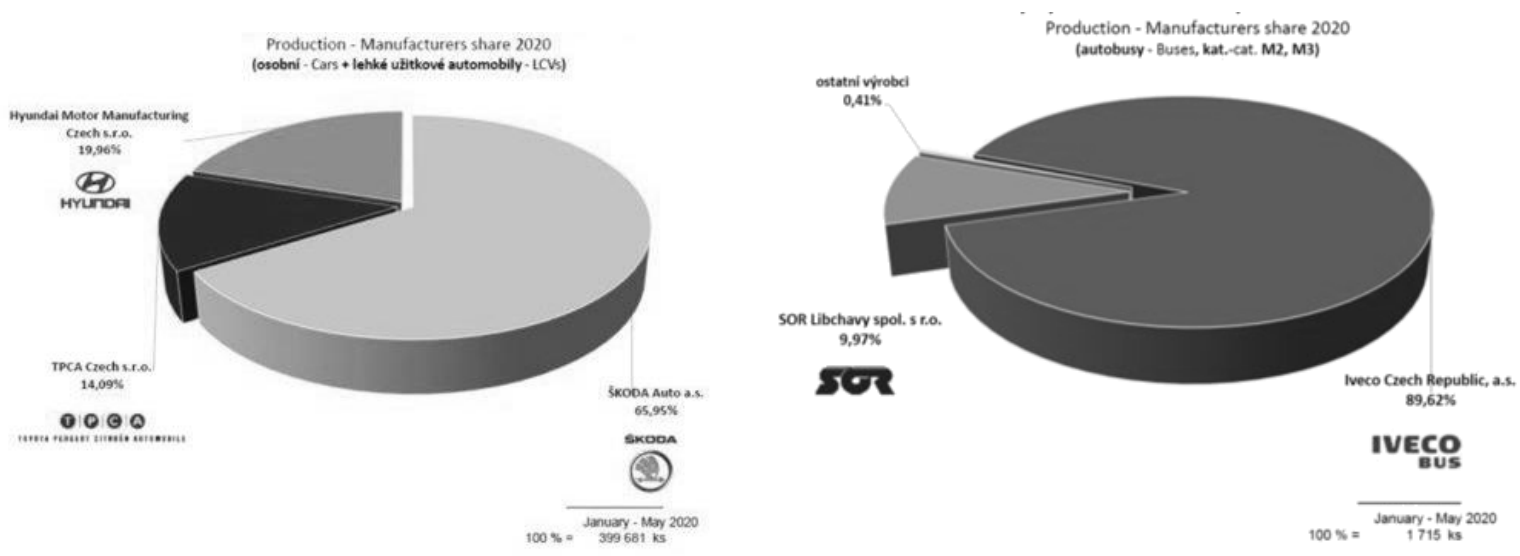

Figure 2 Manufacturers' proportions of the automotive market in the Czech Republic [3]

The supply chain is thus broken and a higher degree of use and demand for low carbon wire produced in the Czech Republic is not considered. Figure 3 shows the current state in a simplified graphic form.
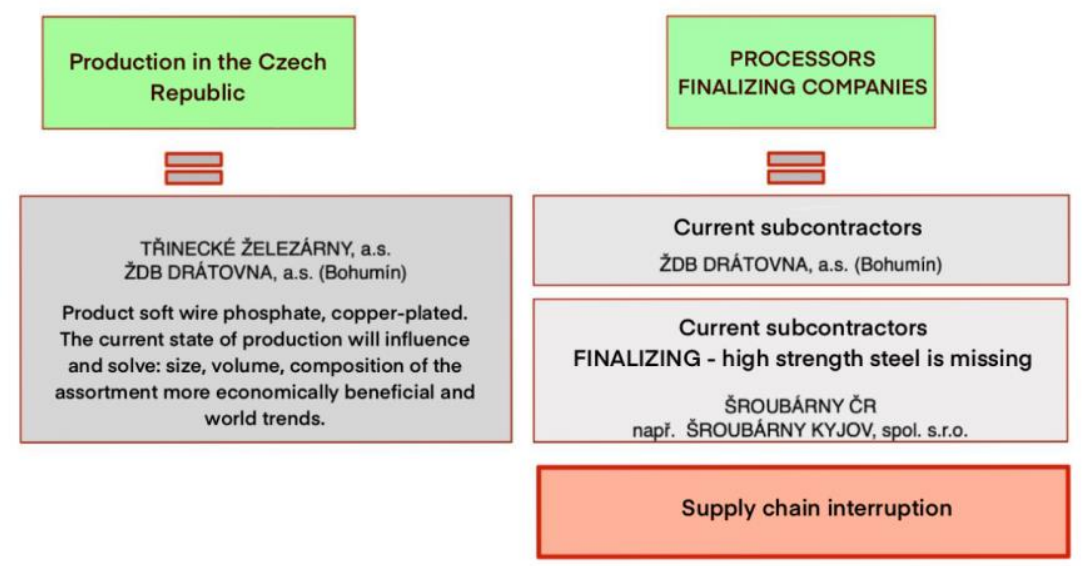

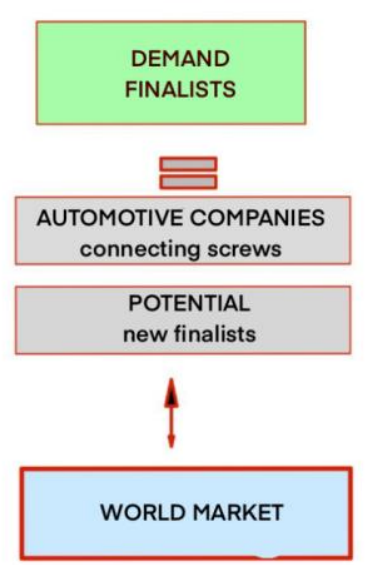

WORLD MARKET

Figure 3 Current business structure identified by the research for potential change

The questionnaire surveys and results of the study on a higher degree of use and demand for low-carbon wire were applied to create a new potential business model, illustrated simply in Figure 4.

In many case studies, this area of research has failures. Although the literature provides studies on material safety, which is closely related to the topic, and indispensable knowledge of raw materials and marketing, foreign studies do not align with the specific problem of low-carbon wire production in the Czech Republic [3-11]. 


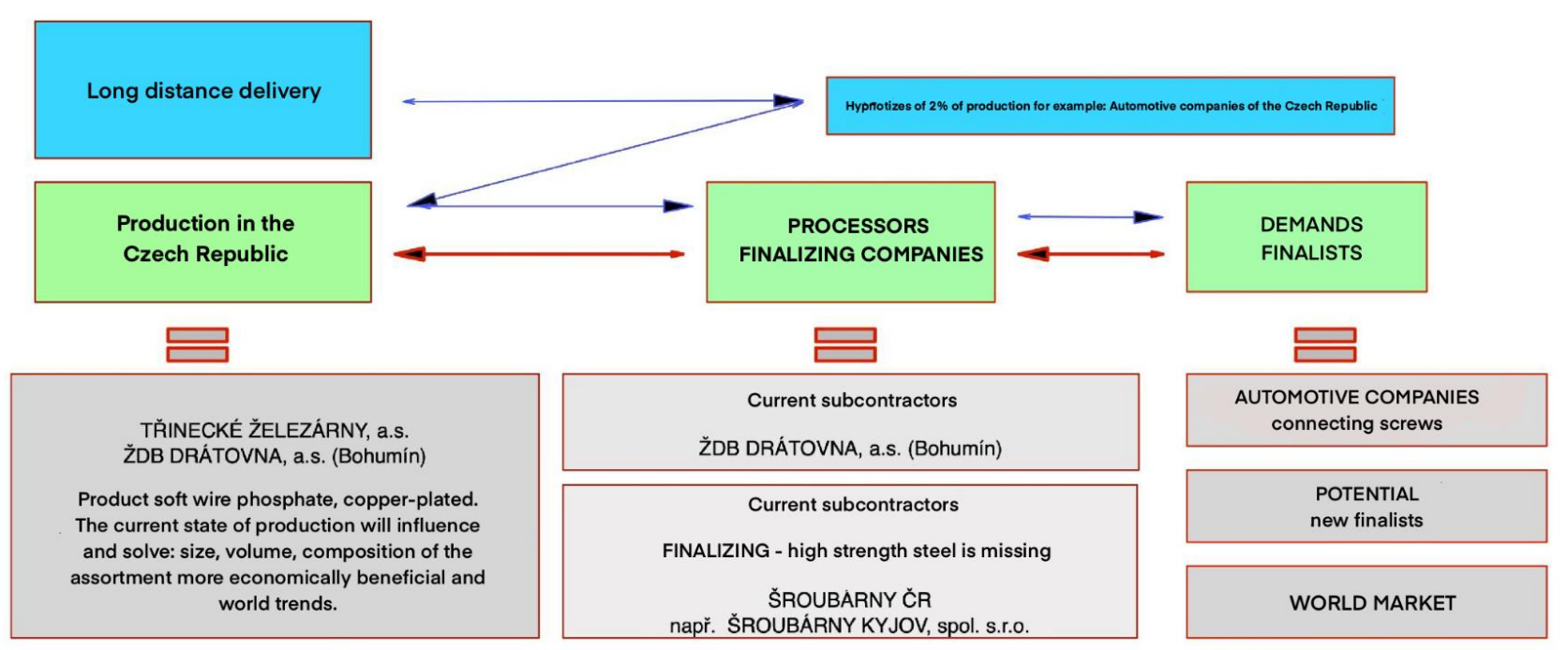

Figure 4 Simplified model of the potential business structure identified by the research

At RMTVC, the research in this area has focused on material safety and published various results. However, RMTVC is not currently further investigating this issue, and research and development essentially addresses the task of the primary producer $[12,13]$. The new business model would provide a link between research and development with the RMTVC material center's available laboratory technology and the various low-carbon wire processors and thereby address their future competitiveness on world markets in 2025-2030.

\section{RESULTS}

Further research and the monitoring of research and development offers basic solutions primarily aimed at the tasks of the final producer. Research should, however, further address areas where the potential for high added value exists, i.e., at the final link at the end of the chain. Up to $80 \%$ of steel research tasks currently concern the primary steel producer, not the group of finishing companies which use steel in the automotive and food industries.

The automotive industry conceals a large number of deliveries. Production also involves galvanic treatment, cadmium plating, and plating of special parts for use in the industry. Another group are customers with belowthreshold consumption. We hypothetically ask what would the result be if the percentage changed by only $2 \%$ ? What would occur and how would the importance of finishing companies be strengthened?

The production output of automobile factories could contain $70 \%$ of production, which, when converted, is no longer simply a transient number in the form of screws per kilogram of each car produced. To illustrate, a car weighs $1440 \mathrm{~kg}$, of which $814 \mathrm{~kg}$ of production is from the smelter containing $20 \mathrm{~kg}$ of low-carbon wire bolts. The potential is the production of 600,000 cars which contain 1,200,000 pieces, i.e., $70 \mathrm{~kg}$, per car.

All of the above is derived from research and relates to the structure of the entire economy, i.e., with a higher degree of use and demand for low-carbon rolled wire produced in the technological chains of secondary metallurgical production and engineering in the Czech Republic.

\section{CONCLUSION}

The research results suggest that the issue of utilization and demand for low-carbon wire produced in selected branches of secondary metallurgical production in the Czech Republic lies in disconnected technological processes, which results in less production of finished products in the country. The raw material manufacturing 
chain ends with the export of raw materials, i.e., semi-finished products, and consumers in the Czech Republic do not benefit from the higher added value of low-carbon wire produced by the finishing phase. Further research will be conducted for a dissertation and will apply marketing product segmentation models to investigate a new and essential business model. At present, the production chain is broken and contains a low volume of deliveries, i.e., the demand from the end consumers of Czech subcontractors who purchase from manufacturers outside the domestic market is satisfied by deliveries of unknown and fluctuating quality, despite the fact that high-quality low-carbon wire can be adequately produced according to customer requirements in the Czech Republic. For the reasons outlined in the findings above, Czech manufacturers are experiencing a shortfall.

\section{ACKNOWLEDGEMENT}

The work was supported by specific university research of the Ministry of Education, Youth and Sports of the Czech Republic, No. SP 2021/71.

\section{REFERENCES}

[1] STEEL UNION: Statistiky. Ocelářská unie [online]. 2020 [cit. 2021-03-20]. Dostupné z: https://www.ocelarskaunie.cz/ocelarstvi/statistiky/

[2] EUROFER. Annual Report [online]. Belgium: European Steel Association, 2020. [cit. 2021-03-20]. Dostupné z: https://www.eurofer.eu/assets/Uploads/Annual-Report-2020

[3] Český průmysl se rozjiždí jen po zvolna. Periskop [online]. 2020 [cit. 2021-03-20]. Dostupné z: https://autoperiskop.cz/cesky-autoprumysl-se-rozizdi-jen-pozvolna//

[4] AMIT, R., ZOTT, C., \& MASSA, L. The business model: recent developments and future research. Journal of Management. 2011, vol. 37, no. 4, pp. 1019-1042.

[5] JANSEN, W., STEENBAKKERS, W., \& JÄGERS, H. New Business Models for the Knowledge Economy. Hampshire, UK: Gower Publishing, Ltd., 2007

[6] MAGRETTA, J. Why business models matter. Harvard Business Review. 2002, vol. 80, no. 5, pp. 86-92.

[7] ZOTT, C., AMIT, R. \& MASSA, L. The business model: Theoretical roots, recent developments, and future research. IESE Business School-University of Navarra. 2020, pp. 1-43.

[8] TEECE, D. J. Business models, business strategy and innovation. Long range planning. 2010, vol. 43, no. 2, pp. 172-194.

[9] MAGRETTA, J. Why business models matter. Harvard Business Review, 2002, vol. 80, no. 5, pp. 86-92.

[10] LAMBERT, S. A Review of Electronic Commerce Literature to Determine the Meaning of the Term 'Business Model'. School of Commerce Research Paper Series. 2002, pp. 2-3.

[11] CHESBROUGH, H. Open business models: How to thrive in the new innovation landscape. Harvard Business Press. 2013

[12] HEDMAN, J., KALLING, T. The business model concept: theoretical underpinnings and empirical illustrations. European Journal of Information Systems. 2003, vol. 12, no. 1, pp. 49-59.

[13] KUCHTIČKOVÁ, Iveta, NÉTEK, Václav, DRÁPALA, Jaromír, NĚMCOVÁ, Nikola and NĚMEC, Tomáš. Materiál safety of low-carbon wire supply chains in the Czech Republic in selected fields of metallurgical secondary production. In METAL 2020. Brno: Tanger, 2020.

[14] NĚMEC, Tomáš, NÉTEK, Václav, MYNÁŘ, Martin, NĚMCOVÁ, Nikola and KUCHTIČKOVÁ, Iveta. Selected aspects of technological thought in economy according to the conditions of industry 4.0. In METAL 2020. Brno: Tanger, 2020 